\title{
Rural English Language Teacher IDENTities: Alternative Narratives of Professional Success
}

\author{
IDENTIDADES DE DOCENTES RURALES DE INGLÉS: NARRATIVAS ALTERNATIVAS \\ DE ÉXITO PROFESIONAL \\ IDENTITÉS DES ENSEIGNANTS D'ANGLAIS EN MILIEU RURAL : NARRATIVES ALTERNATIVES \\ DE RÉUSSITE PROFESSIONNELLE
}

\section{Ferney Cruz-Arcila}

Ph. D. in Language Discourse and

Communication, King's College,

London.

Associate professor, School of

Humanities and Social Sciences,

EAN University, Bogotá D. C.,

Cundinamarca, Colombia.

cruzferney@gmail.com

https://orcid.

org/0000-0002-9185-9392

\begin{abstract}
This article problematizes the notion of professional success in English language teaching as constructed in language policy in Colombia. This is done by examining one of the most underexplored social diversities in the field: rural schools. Stemming from a narrative study on how rural English language teachers configure their professional identities vis-à-vis the situated circumstances of their work settings and external pressures, this analysis shows that teachers' sense of professional success is negotiated in creative, complex, and multiple-although not always consistent-ways, which represent alternative constructions of good teaching to those promulgated in policy. It is argued, then, that a reconfiguration of the belief systems of what teachers should know and do is necessary.
\end{abstract}

Keywords: language teaching; rural teachers; professional success; teacher identity; narratives, English teachers.

\section{RESUMEN}

Este artículo problematiza la noción de éxito profesional en la enseñanza del inglés, según se construye en la política lingüística en Colombia. Esto se hace examinando una de las diversidades sociales menos exploradas en el campo: las escuelas rurales. A partir de un estudio narrativo de cómo los profesores rurales de inglés configuran sus identidades profesionales en relación con las circunstancias situadas en sus entornos de trabajo y presiones externas, este análisis resalta que el sentido de éxito profesional de los maestros, aunque no siempre consistente, se negocia de manera creativa, 
compleja y múltiple, lo que representa construcciones de buena enseñanza alternativas a las promulgadas en la política. Se argumenta, entonces, que es necesaria una reconfiguración de los sistemas de creencias sobre lo que los maestros deben saber y hacer.

Palabras clave: enseñanza de lenguas; profesores rurales; éxito profesional; identidad del profesor; narrativas; profesores de inglés.

\section{RÉSUMÉ}

Cet article traite de la notion de réussite professionnelle dans l'enseignement de l'anglais, tel que le conçoit la politique linguistique en Colombie. Ceci en examinant une des particularités sociales les moins traitées dans le domaine: les écoles rurales. En se basant sur l'étude de la construction de leur propre identité professionnelle par les professeurs rurales d'anglais, en relation avec les conditions situées de l'environnement de travail et les exigences extérieures, cette analyse souligne que le sentiment de réussite professionnelle des enseignants s'élabore de façons créatives, multiples et complexes, et pas toujours cohérentes, qui représentent une construction alternative aux bonnes pratiques de l'enseignement tel que défini par la politique. Je soutiens, alors, qu'une reconfiguration des systèmes de croyances sur ce que doivent savoir et faire les enseignants est nécessaire.

Mots-clés : enseignement de langues ; enseignants ruraux ; réussite professionnelle; identité de l'enseignant; narratives ; enseignants d'anglais. 


\section{Introduction}

Although conceptions of what effective or good teaching and, thus, "good" teachers have been considered a subjective and culturally attached matter (Richards, 2010), some views on what teachers must do to appear or be positioned as successful professionals have become more widespread than others. In the case of English language teachers, the requirements they have had to meet tend to center on issues such as their language proficiency, content knowledge, pedagogical knowledge, teaching skills, and, in some cases, familiarity with specific sociocultural contexts (Richards, 2010). In a more general sense, good teaching is measured against "what teachers know and are able to do to teach languages effectively" (Graves, 2009, p. 117). It is common to find that in this understanding of good teaching, there is an emphasis on the technical aspects of what teachers should know and do. For example, examining the notion of good teachers as portrayed in public policy in the United Kingdom, Troman (1996) concluded that there was a "marked emphasis on teacher competences, technical skills and managerial attributes in official constructions of the 'good' teacher" (p. 33).

In Colombia today, the situation is not far from the same technical approach. Since 2004, the Ministry of National Education (Colombia, Ministerio de Educación Nacional, 2005, 2014), has been implementing nation-wide English language teaching (ELT) policies that prioritize English as the preferred foreign language to be taught in public schools. One of the most controversial goals of such policies has been the idea that secondary school graduates should achieve a B1 level of proficiency within the Common European Framework of Reference (CEFR), which today is achieved by only $6 \%$ of them (Colombia, Ministerio de Educación Nacional, 2018). (See Cruz-Arcila, 2017 for a full discussion on how teachers have enacted this policy). Further critiques by Colombian scholars such as Guerrero (2010); Correa, Usma, and Montoya (2014); and Sierra-Piedrahita (2016) have addressed how, from the vantage point of policy makers, as can be seen in the policy documents, there is a tendency to identify English language teachers in general as technicians who need to further develop their skills in order to better deliver on the instructions the relevant authorities give them (e.g., curricular guidelines and specific teaching methodologies) and thus attain the policy goals.

Guerrero (2010) argues that identifying teachers of English in such a way ignores and undervalues their voices and knowledge. They are expected to "just follow orders" (Guerrero, 2010, p. 35) and focus on achieving the prescribed goals. This is why teachers not reaching policy goals, and not doing well on international examinations-as has widely happened so far-are likely to be considered enough evidence to identify teachers as unsuccessful professionals, as shall be illustrated below. However, as we will also see in this article, teachers' own sense of good teaching can be grounded in other more situated factors.

This paper discusses the results of research aimed at examining the ways in which rural English language teachers in Colombia configure their practices and professional identities in light of two groups of factors: (a) the national ELT policy (its architecture, goals, and demands) and (b) the teachers' rural sociocultural contexts (social issues and the communities' values, problems, possibilities, and aspirations). Analyses on the configuration of practices and what it takes to teach English in rural Colombia have already been published (see CruzArcila, 2018a, 2018b). The current analysis focuses particularly on the construction of professional identities. Drawing on a sociocultural perspective of language teacher identity, this paper examines how teachers tend to construct alternative yet conflicting narratives vis-à-vis the sense of professional success and good teaching promulgated in policy.

The article starts by briefly discussing the notion of teacher identity from a sociocultural perspective then uses it to illustrate different ways to understand professionalism in language education. This is followed by a discussion of the analytical 
approach to identity that guided the analysis, a description of research methods, and a characterization of the participants of the study. Then the discussion moves on to examine the process by which the participating teachers constructed identifications of themselves as successful professionals and how such self-identification was built on an alternative meaning of success that moves away from policy compliance. The paper ends by discussing the findings presented and offering some concluding thoughts.

\section{Theoretical Framework}

This section discusses the main theoretical underpinnings of the analysis. Since the study focuses on how both external pressures such as educational policies as well as localized contextual circumstances of rural schools may shape teachers' identities, the discussion first grapples with a sociocultural perspective on teacher identity. In relation to this, different ways to understand teacher professionalism is, then, spelled out. The section ends with a description of the analytical frame used to add precision to what is understood by "identity" in the study.

\section{A sociocultural View on Teacher Identity}

The study of teacher identity has gained significant ground in recent years since it has been recognized that what happens in the classroom is, to a large extent, a reflection of each teacher's own understanding of their profession in relation to their larger social, cultural, and political context (Miller, 2009; Varghese, Morgan, Johnston, \& Johnson, 2005). In the field of applied linguistics, it is now commonly accepted that the role of the teacher is not limited to that of a technician who must follow a given set of pre-established methodological principles to achieve certain learning goals. Instead, scholars interested in the study of teacher identity point out that teachers' ideas of who they are and of what teaching should be directly impact daily practices in the classroom (Barkhuizen, 2016; Day, Kington, Stobart, \& Sammons, 2006; Varghese, Motha, Trent, Park, \& Reeves, 2016).
This is how, in the field of language teaching, the growing body of research on teacher identity has come to be concerned with its intricate relationship with a variety of factors, such as teacher cognition (what teachers think, know, believe, and do) (Borg, 2009; Kubanyiova \& Feryok, 2015), experiences (both learning and teaching), practices (Flores \& Day, 2006; Olsen, 2016; Sayer, 2012; Scholes Gillings de González, 2011), emotions (Song, 2016; Wolff \& De Costa, 2017), as well as discourses and positioning (Kayi-Aydar, 2015; Morgan, 2004; Pavlenko, 2003). In these cases, it has frequently been necessary to also relate identity formation to contextual conditions as well as to social, cultural, and political factors mediating education.

This multiplicity of factors has led to the emergence of various definitions for "identity." Some of these definitions include the idea that it is determined by the ways in which a "person understands his or her relationship to the world, how that relationship is constructed across time and space, and how the person understands possibilities for the future" (Norton, 2000, p. 5). Related definitions address identity as a dynamic process of "making sense and (re)interpretation of one's own values and experiences" (Flores \& Day, 2006, p. 220), as being recognized as a certain "kind of person" in a given context at a given moment (Gee, 2000, p. 99), or as the ways in which one participates in communities of practice (Wenger, 1998).

The above definitions go beyond the idea that identity is pre-established and static, that it is a psychological or a biological characteristic. Instead, to different degrees these conceptions describe identities as arising from sociocultural factors. That is, in the case of teachers, the configuration of identities results from the influence of contextual factors and the negotiation that comes along with those factors. This influence, as Norton (2000) suggested, is constructed across time and space and is conflicting and changing. At the same time, as Flores and Day (2006) argued, the context leads us to negotiate our own values and experiences. Gee (2000) stressed the importance of interaction with others 
in developing a sense of who one is, as this sensemaking process is necessarily mediated by how one is (or is not) recognized in a social context. Wenger (1998) insisted on this social dimension as a sense of identity developed according to how one affiliates with different communities of practice and takes part in them.

In resonance with these sociocultural views, Olsen (2016) offered a compelling definition of teacher identity. For him, it is

a term to describe both the active process of using personal and professional, past and present influences in order to enact one's teaching and teacher learning, and the resulting product: that dynamic assemblage of influences-and-effects (and I connect the words "influences" and "effects" with hyphens to emphasize their interconnectedness) that is always guiding a teacher's perspectives and practices. (p. 48)

Just like Norton (2000), Olsen (2016) emphasized the idea that teacher identities are shaped by prior, current, and-as Norton (2000) also highlighted-upcoming personal experiences as well as experiences as learners and teachers that have taken or will take place in different contexts. Therefore, interpretations of the world, including what teaching is about, derive directly from the influences and effects of such experiences.

As an illustrative metaphor, Olsen (2016) compared teacher identity with a pair of unique glasses "constructed out of the materials of our own personal histories" (p. 44), through which the world of teaching and all its factors are interpreted. As a result of such interpretations, he argued, teachers make decisions that shape their practices and construct ideas of the extent to which these practices are successful. These glasses also influence the diverse terms in which teachers may develop relationships with their teaching contexts (e.g., colleagues, administrators, policies, and the community). It follows that, as more experiences are lived, the interpretive frame of the glasses is adjusted, allowing us to see different shades in the interpretations we can make at different points in time.
The following working definition of the term "language teacher identity" (LTI) can also be used to draw special attention to its sociocultural nature:

Language teacher identities (LTIS) are cognitive, social, emotional, ideological and historical-they are both inside the teacher and outside in the social, material and technological world. LTIs are being and doing, feeling and imagining and storying. They are struggle and harmony: they are contested and resisted, by self and others, and they are also accepted, acknowledged and valued, by self and others. They are core and peripheral, personal and professional, they are dynamic, multiple and hybrid, and they are foregrounded and backgrounded. And LTIs are short-term and overtime-discursively in social interaction with teacher educators, learners, teachers, administrators, and the wider community, and in material interaction with spaces, places and objects in the classroom, institutions and online. (Barkhuizen, 2017, p. 4)

This definition underscores the idea that the identities of teachers should be seen as a complex phenomenon with multiple iterations, hence the use of the plural for the term "identities." In agreement with Norton (2000) and Olsen (2016), this definition highlights that identities are dynamic and may at times enter a state of struggle as they are developed at different points in time, under different social circumstances, and in interaction with different people in different locations. Thus, it follows that LTIs are not solely a cognitive process but also the result of socialization and interaction with others who may accept, resist, or assign such identities. In line with the discussion in the preceding sections, Barkhuizen's (2017) definition considers the affective dimension, historicity, and future imaginings of teachers as key factors in how they shape images of themselves.

Barkhuizen's (2017) definition also recognizes teachers' engagement with pedagogic materials as well as physical and online spaces as important players in their self-understanding as teachers. At the same time, in this definition, Barkhuizen (2017) stressed the idea that LTIs are both enacted and constructed discursively; that is, ideas of who teachers are shape their actions and the things they say. 
This point is complemented with the argument that the things teachers say and do also shape their ideas of who they are (Kanno \& Stuart, 2011; Morgan, 2004).

To sum up, in light of the above definitions, this analysis follows a sociocultural understanding of LTIs by considering identities as situated and thus highly influenced by contextual factors such as education policies, cultural values, and socioeconomic circumstances, as well as the social struggles of their students and the communities teachers may take part in. This paper will treat the sense of who teachers are as having been developed in negotiation with those factors across time and space, and it will consider them evident in their discursive recreation of both their histories and future imaginings as they narrate their experiences. As this understanding of who teachers are is dependent on the (non)recognition they could obtain from others in social interactions, the images teachers construct of themselves are likely to shift and enter into conflict.

This view of identity, as I argue in the next section, offers appropriate theoretical ground for analyzing different strands of belief around teacher professionalism.

\section{Teacher professionalism and identity}

As discussed, from a sociocultural view of teacher identity, teachers' sense of who they are is the result of multiple factors. Identity is not seen as something biologically or cognitively predetermined but, on the contrary, as being constructed by means of the relationships we establish with the world at different points in time, under different circumstances (Norton, 2013; Olsen, 2016). This multiplicity of factors, I argue, can also play an important role in shaping notions of teacher professionalism. Situated circumstances, teacher experiences, community problems and aspirations, as well as the demands of policy makers and the market are some of the factors that may come to shape different understandings of good teaching.
To illustrate this argument, I will draw on Leung (2009), who defines a professional as "a trained and qualified specialist who displays a high standard of competent conduct in their practice” (p. 49). From this definition, he proposes two different ways in which professionalism can be viewed: sponsored professionalism and independent professionalism (Leung, 2009). The former refers to institutionalized, top-down views on professionalism usually "promoted by regulatory bodies to introduce reform and/or by professional associations to advocate change" (Leung, 2009, p. 49). The latter, in contrast, highlights a bottom-up, socially and historically sensitive sense of professionalism.

According to Leung (2009), sponsored professionalism is more likely to be the approach adopted by policy makers in the implementation of education policies that are aligned principally with market interests, as is the case of the ELT programs in Colombia. In this sense, professionalism in teachers is usually constructed upon technical principles of knowledge of the subject matter and delivery of curricular guidelines and teaching methodologies with the aim of attaining given goals. On the other hand, the independent understanding of professionalism considers professional success to be more locally grounded in specific contexts and gives more weight to the sense individual teachers have of how their work is perceived and appreciated and how appropriately they have tailored their professional actions in relation to the circumstances and social circumstances they are immersed in.

Under the sponsored sense of professionalism, then, negative identifications of teachers are likely to emerge if they do not meet the goals established by policy makers, which is, in turn, taken as a valid reason to question the content and pedagogical knowledge they are expected to possess. For example, when reporting on the low performance of Colombian students on the Program for International Student Assessment (PISA) ${ }^{1}$ exam-

1 PISA is a triennial international survey which aims to evaluate education systems worldwide by testing the 


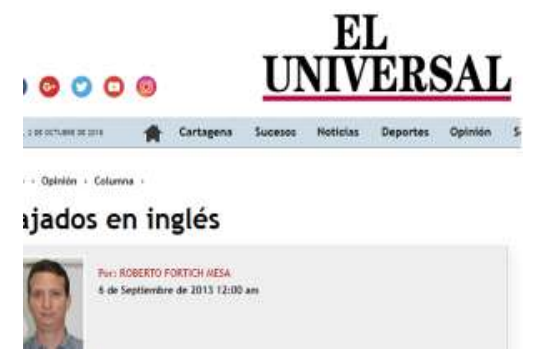

Figure 1 News headline from El Universal Note: The headline "Rajados en inglés" can be roughly translated to "Flunking English" (Fortich Mesa, 2013, September 6).

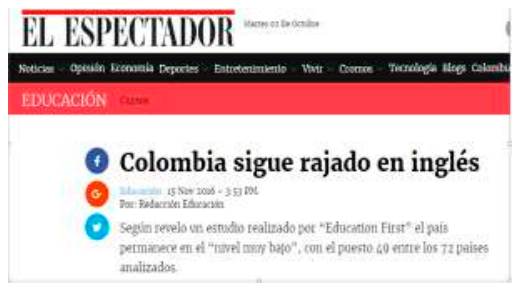

Figure 3 News headline from El Espectador Note: The headline "Colombia sigue rajado en inglés" can be roughly translated to "Colombia still Flunking English" (El Espectador, 2016, November 15).

inations or in a ranking of countries by English skills conducted by English First $(\mathrm{EF})^{2}$ (see Figures 1 to 4 ), media reports tended to portray teachers as the primary cause of the supposed or assumed failure.

The news report from El Universal (Figure 1) discussed how Colombia is struggling to get proficient in English, describing it as the language of economic development in times of globalization. It then explained that low English proficiency was caused by the fact that it is not taught effectively (Fortich Mesa, 2013).

skills and knowledge of 15 -year-old students. This test is implemented by the OECD (The Organization for Economic Co-operation and Development), a European transnational organization promoting public policy around the globe.

2 English First is an international education company focused on English language training courses. It has offices in over 107 countries.

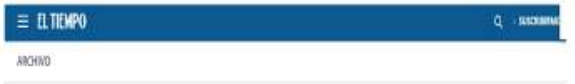

¿Por qué es tan mala la educación en Colombia?

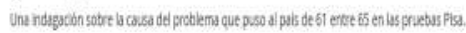

Figure 2 News headline from El Tiempo Note: The headline "Por qué es tan mala la educación en Colombia" can be roughly translated to "Why education is so poor in Colombia” (Gossaín, 2014, February 27).

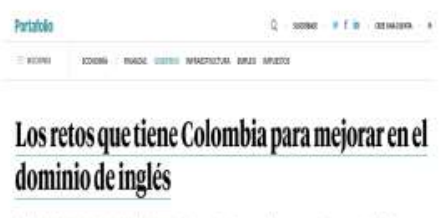

Figure 4 News headline from Portafolio Note: The headline "Los retos que tiene Colombia para mejorar el dominio del inglés" can be roughly translated to "The challenges of Colombia to improve proficiency in English." The image is a screenshot taken from Portafolio (2017, November 16).

In response to the question asked in its headline, the article from El Tiempo (Gossaín, 2014, February 27 ) in Figure 2 argued that poor quality of education in Colombia is a result of the poor quality of its teachers. It went on to explain the poor proficiency level in English by rhetorically asking how students can be expected to speak English if their teachers cannot (Gossaín, 2014).

Figure 3 depicts the headline of an article from $E l$ Espectador newspaper (2016, November 15). As in the headline in Figure 1, this article used the verb rajar (a term used in regional Colombian Spanish to mean "to flunk") when reporting that Colombia continues to perform poorly in English. It showed that, according to the results of an English proficiency test administered by EF, Colombia ranked among the countries with a very low level of English, taking $10^{\text {th }}$ place out of 14 countries in Latin America (El Espectador, 2016, November 15). 
Oneyearafter the ElEspectador (2016, November 15) story, Portafolio (2017, November 16), whose headline can be found in Figure 4, hit a slightly more positive note when it reported that, although Colombia is still performing badly on the test administered by EF, it is now classified in the group of countries with a low level of proficiency, as opposed to the very low category it had fallen into previously. This indicates a slight improvement. However, in a more recent article published in November 2018, the same magazine reverted to reinforcing the idea that the country is not meeting the government's expectations of improving proficiency in English (Portafolio, 2018, November 8).

After examining these five media reports from different popular Colombian newspapers, it can be observed that teachers tend to be held responsible for the lack of success in international examinations. And the same stories follow up by suggesting that the solution is to improve the quantity and quality of English language teachers (Fortich Mesa, 2013), establish more ways to monitor and evaluate teachers, or import more native English language teachers (Portafolio, 2017, November 16). The general message from these five news pieces seems to be that Colombian English language teachers are ineffective from a sponsored view of professionalism.

After this brief review of how media seem to construct identifications of teachers in rather negative terms, a question that arises is, how do teachers identify themselves? Or, in other words, what would count as "a high standard of competent conduct” (Leung, 2009, p. 49) from an independent sense of professionalism? These questions are especially relevant when analyzing rural contexts, where education policies are challenged by unique social issues such as extreme poverty, deprivation, under-resourced schools, child labor, and limited access to higher education (Lackin \& Gasperini, 2004; López \& Núñez, 2007; Perry, 2010; Programa de las Naciones Unidas para el Desarrollo, 2011). From a sociocultural perspective, these issues come to bear in configuring teachers' identities as professionals. Before I address these issues, though, it is important to discuss the analytical framework from which the notion of identity will be approached in this paper as well as some key aspects of the research methods followed.

\section{Analytical Framework of Identity}

In their theorization of language teacher identity, Varghese et al. (2005) explained that the notion of identity is usually addressed as being multiple, shifting, and in conflict. Similarly, in a review of the definitions of teacher identity in the field of TESOL, Miller (2009) concluded that identity is usually regarded as being "relational, negotiated, constructed, enacted, transforming and transitional" (p. 174). These multiple traits assigned to the notion of identity seem to respond mainly to post-structural tendencies that emphasize a changing and unstable idea of this concept (Miller, 2009). At the same time, however, the multiple connotations have loaded the scope of "identity" with such a high level of ambiguity that the term risks losing its value as a useful category of analysis (Brubaker \& Cooper, 2000).

In order to address the problem of ambiguity, and aligned with the sociocultural view of teacher identity discussed above, the present scrutiny benefits from Brubaker and Cooper's (2000) nuanced analytical approach to the notion of identity. These authors argued that in order to add analytical precision to all the meanings usually associated with the term "identity, an alternative intertwined set of terminology can be useful. They proposed three clusters of terms: (a) identification and categorization (how one self-identifies or is identified by others in specific situations); (b) self-understanding and social location (the sense of who one is in relation to the social context and how one acts accordingly); and (c) commonality, connectedness, and groupness (different ways one can feel a member of a given group and the degrees to which they do so). As Brubaker 
and Cooper (2000) argued, these terms are useful when examining multiple issues related to a sense of being with much more analytical precision than the "heavily burdened" (p. 8) term "identity" can offer. This is because this term has been used to mean many things, which in turn has made it highly vague and of little use for analytical purposes.

The use of this analytical toolkit makes it possible to approach identity formation as a process rather than a state, which at the same time permits exploration of tensions between identifications of teachers made by others and those made by themselves in different situations and points in time. It has also been useful in pinning down ways in which participants have understood the implications of being rural teachers as well as the ways in which they have established ties with both rural communities and communities of teachers of English. Due to space restrictions, this article will focus exclusively on how teachers are identified and self-identified as professionals. As we will see, this analysis sheds important light on how they develop situated understandings of what can be considered good teaching. In other papers the idea of how teachers self-understand and how they relate to the rural community will be examined.

\section{Method}

This study follows an interpretative and narrative approach. According to Lincoln, Lynham, and Guba (2011), in interpretative research, knowledge is reached by means of a process of interaction between the inquirer and the inquired. Knowledge is not taken as universally valid but as a changing body of values (Scott \& Usher, 2011), and, as such, the relationship between the researcher and participants is crucial in co-constructing understandings about the phenomenon of interest. The co-construction and collaborative understanding in this study took place by means of teachers sharing their professional life histories and experiences and by me triggering and interpreting them. The study as a whole used written professional life histories, two in-depth interviews, and fieldobservations as data collection techniques.

This paper focuses only on the data collected by means of the two rounds of interviews: the first before and the second after the field observations. The main purpose of using interviews was to reach deep accounts of teachers' understandings, opinions, and insights regarding the endeavor of teaching English in rural settings. Thus, the interviews focused on the ways in which teachers said they followed, assimilated, integrated, or modified their practices in response to both language policies and rural sociocultural particularities. At the same time, through the oral narratives emerging from the interviews, I obtained information regarding the meanings the teachers constructed about who they are and how they feel they are supposed to act as professionals in light of the policies and the social context of their rural work-settings. These interviews were carried out in Spanish, and then translated into English. In an attempt to echo the voices of teachers naturally, their narratives were not modified or corrected.

\section{Participants}

Ten rural English language teachers from seven different regions of Colombia participated in this study. They were recruited on a voluntary basis and, as they were from different regions, they did not constitute a homogeneous group. As shown in Table 1 below, their level of proficiency in English, years of experience, contexts they have worked in, places of origin, and work statuses were some of the most striking variables among the group.

As presented in Table 1, some teachers believed their proficiency level ranged from $\mathrm{B} 1$ to $\mathrm{B} 2$, according to CEFR guidelines. This information was voluntarily disclosed, and four participants (Clara, Camilo, Lily, and Jairo) opted not to make specific allusions to their proficiency level. As we shall see later, nonetheless, teachers' perceptions in this regard came to bear strongly in their sense of who they are as professionals. With respect to the 
number of years into the teaching profession, we can see that most participants (six) were highly experienced with over 15 years of teaching. The other four teachers' experience ranged from 5 years (Arturo) to 10 years (Hilda). It can therefore be said that although none of the participants was a novice teacher, there may be a big difference in the richness of experiences between the most and least experienced.

Referring now to the contexts in which the participants' work experiences have taken place, the table shows that, except for Maria and Hilda, who have only worked in rural schools, most teachers had prior experience in urban contexts too. This is another salient factor in the heterogeneity of the participants, which connects with the origin variable of Table 1 . While only three teachers came from rural families, the other seven appeared to have gained familiarity with rural life mainly through their professional practice. Finally, in terms of their work status, at the time of the study, three teachers had been unable to find a permanent position and were therefore not as stable as the others, as these three teachers might be removed from their workplaces or transferred at any time.

This heterogeneity necessarily makes every teacher unique, and thus, as Olsen (2016) states, talking about their identity is a way to celebrate that uniqueness. However, Olsen (2016) also suggests that uniqueness leaves room for some shared understandings, conflicts, contradictions, and positionings with other teachers. In this context, informed by the factors that make each participant different, this analysis aims to find points of convergence in an attempt to build the case for common understandings and undertakings among participants. It is in this spirit that the discussions on teachers' identifications as professionals are developed in this paper.

\section{Results}

This section will discuss the main results of the analysis. It will show how teachers find alternative

Table 1 Heterogeneity across participants

\begin{tabular}{|c|c|c|c|c|c|c|c|c|c|}
\hline \multirow[t]{2}{*}{$\begin{array}{c}\text { Teacher } \\
\text { (pseudonym) }\end{array}$} & \multirow[t]{2}{*}{$\begin{array}{l}\text { Level of } \\
\text { English } \\
\text { reported }\end{array}$} & \multicolumn{2}{|c|}{$\begin{array}{c}\text { Years of } \\
\text { teaching } \\
\text { experience }\end{array}$} & \multicolumn{2}{|c|}{$\begin{array}{c}\text { Context of work } \\
\text { experience }\end{array}$} & \multicolumn{2}{|c|}{ Origin } & \multicolumn{2}{|c|}{ Work status } \\
\hline & & $\geq 15$ & $\leq 10$ & $\begin{array}{c}\text { Rural \& } \\
\text { Urban }\end{array}$ & $\begin{array}{l}\text { Only } \\
\text { rural }\end{array}$ & Rural & Urban & Permanent & Provisional \\
\hline Ana & B2 & $x$ & & $x$ & & & $x$ & $x$ & \\
\hline Maria & $\mathrm{Bl}$ & $x$ & & & $x$ & $x$ & & $X$ & \\
\hline Dora & B2 & $x$ & & $x$ & & & $x$ & $x$ & \\
\hline Clara & NG & $x$ & & $x$ & & & $x$ & $x$ & \\
\hline Camilo & NG & $x$ & & $x$ & & & $x$ & & $x$ \\
\hline Lily & NG & $x$ & & $x$ & & $x$ & & $x$ & \\
\hline Eva & $\mathrm{Bl}$ & & $x$ & $x$ & & & $x$ & & $x$ \\
\hline Hilda & $\mathrm{Bl}$ & & $x$ & & $x$ & & $x$ & $x$ & \\
\hline Arturo & B2 & & $x$ & $x$ & & $x$ & & & $x$ \\
\hline Jairo & NG & & $x$ & $x$ & & & $x$ & $x$ & \\
\hline
\end{tabular}

$\mathrm{ng}=$ Not given 
ways of constructing professional success to those promulgated by education bodies and policy makers. As will be made clear, the results suggest that such identifications can be made in relation to both how the school community has positioned these teachers and how teachers construe professional images of themselves.

\section{Teachers' Identifications: Creating Alternative Narratives of Success}

As noted, the notion of identification allows us to approach the idea of being as a process occurring in social life under different circumstances by different people (Brubaker \& Cooper, 2000). In this particular case, this analytical concept has been useful to pin down tensions and contradictions between identifications of teachers made by groups in power (e.g., policy makers) and those made by teachers themselves or people they interact with on a daily basis (e.g., colleagues, students, parents). For the purposes of this analysis, I call the former etic identification and the latter emic identification. This study shows how, for instance, these two types of identification seem to be in opposition to one another. As shown in previous sections, from an etic identification perspective, English teachers in Colombia tend to be positioned as ineffective because the country is not doing well on international standardized examinations and because the goals of the ELT policy are not being accomplished (MEN, 2014).

Considering the challenges attached to teaching English in rural contexts such as under-resourced schools, precarious economic circumstances, and poverty (see Cruz-Arcila, 2017), it would not have been surprising that this study would corroborate these ideas of lack of success in teaching English among rural teachers. This would be expected, for instance, insofar as rural students are usually outperformed by their urban counterparts in all national standardized examinations (Delgado, 2014). However, from an emic perspective of identification, data from this study show that teachers construct a quite positive image of who they are: they tend to portray themselves as successful professionals. As shown below, the notion of success for them, however, is built on alternative narratives not necessarily in line with policy compliance but rather with a recognition of their work from what the Canadian philosopher Charles Taylor (see Taylor, 1994) calls "significant others."

In consonance with the sociocultural perspective of identity that this analysis follows, Taylor (1994) viewed the sense of who one is as construed based on interactions with others and on the ways in which one feels (mis)recognized by them. Thus, "significant others" serves to refer to the groups of people who play a significant role in one's life. In the case of teachers of English, it can be argued that the group of significant others includes their students, fellow teachers, school administration, parents, and, in some cases, ELT specialists. One of the study's participants, Arturo, serves as a case in point to illustrate this alternative identification as a successful professional. He felt with certainty that he did his work well not because his students reached high levels of proficiency but because they explicitly recognized his work.

I have really felt that I've done my job. We have not advanced much but my students already know the basic stuff, the elementary things. I wouldn't say that they leave [high school] with a C1 or B2 level [in the CEFR] but my pupils like my lessons a lot. I use images a lot, flashcards. I prepare activities, games. I even treat eleventh graders as little kids ...I bring them activities for primary school kids... they have even told me "Teacher, with the only teacher we feel there is a [learning] process is with you" Those are my students' words. I do think that in the discipline, demand and good lesson planning is where success lies [...] This year a group of students approached me and said to me "Teacher, this is the first time we feel we learn English with a teacher, we are really learning, teacher." (Arturo, interview 1)

In accordance with Norton (2000), this excerpt clearly shows how Arturo's positive identification is grounded in how he understands his relationship to his professional world. Arturo's sense of professional success is that it is the result of hard work, creativity in the implementation of pedagogic 
strategies, and being demanding with students. This suggests he feels that not reaching high levels of proficiency is not due to lack of effort on the part of either himself as a teacher or his students. Thus, the fact that goals are not attained does not directly mean, for him at least, that he has failed as a teacher. On the contrary, the students' recognition of his work counts as an important indicator for him to identify as a good teacher.

In other instances, ideas of success are also fueled by recognition from school administration of the teacher's work based on student achievement, which was the case for Hilda. In the following excerpt, we can see how she was identified by her principal as a successful teacher through a recognition given to her for the work she did in her first year at that school. Compared to previous years with different teachers, Hilda's students had obtained higher results in the English component of the national examination they take at the end of high school, which is called "Pruebas Saber 11".

The pupils I worked with last year, pupils who liked to investigate a lot. Any word they did not understand, anything that -I told them "Ok, it's this word" or they look it up in the dictionary or they observed the word in a text and then asked me, thus they had the motivation, and those pupils did really well in English. They had a score that -higher than the previous years, then it is a satisfaction -it's an acknowledgment that the principal made me. She said to me that it was an acknowledgement as my students had obtained a higher score. (Hilda, interview 2)

Again in this example, the recognition from a significant other in the professional field, in this case a school administrator, seems to play an important role in the ways teachers may create alternative narratives of success to the ones coming from policy makers. In this case, the idea of success is built from a bottom up view of achievement where what counts is not precisely to achieve policy goals as such but, as Hilda implied, to do better than before. However, in this excerpt, it is striking to see the conflicting nature of identity configuration (Norton, 2000; Tsui, 2007; Varghese et al., 2005) as Pruebas Saber 11 is taken as a point of reference to "measure" Hilda's success. This means that policy is not completely absent from this alternative positive construction of professional identification. The identity of a good teacher-grounded in the value given to teachers' hard work and recognition from students and school administration, as shown above-comes to be mediated by the degree of policy compliance. Here is another similar example:

In Armenia was where I found a job [for the first time] in a private school which I liked so much that I even forgot that there were chances [to work in the state sector] ... There I forgot about it because in that school at the end of the year I was evaluated by the principal, the board of parents and the students. They also decided whether we would have a job the following year or if we were sacked ... and I did so well that despite being Pastusa, and with my accent and all that, because when I started to work in Armenia, people said "Here comes the gringa pastusa" ... Thus, despite that, my work was valued in that school and always every year I was given my job again. (Ana, interview 1)

In talking about her first job at a private school, Ana highlights how comfortable she felt there thanks to her work being valued by the entire academic community. Proof of the value given to her work is the job stability she had despite strict and regular evaluations. Interestingly, in this community, she was identified as a "gringa pastusa." This categorization seems to also be a sign of the recognition of her as a valuable and thus successful teacher. To better understand this, it is necessary to spell out what the two terms mean. The term "pastusa/o" is used in Colombia to refer to people from the Southern department of Nariño, as people from this region are thought to have a strong accent in Spanish. The term "gringa/o" is used to refer to foreigners, especially from the United States, and thus, this also associates the term, in Ana's case, with having high proficiency in English. Clustering the two terms seems to be a positive identification of her as a professional teacher because, despite the fact that she had a strong accent in Spanish, she was seen as having a good command of English. 
Even though Ana's experience took place before moving to work in a rural state school, referring back to it now suggests that this categorization has played an important role in her current positive professional self-identification. In this positive identification, we can also observe some tensions between the alternative view of professionalism built from the school community's recognition and Ana as a teacher with a high level of English proficiency, which is one of the key expectations of policy makers. In fact, as shown in Table 1 above, Ana was one of three teachers who described themselves as holding a B2 level of proficiency, meeting policy expectations in this regard.

Leung (2009) presents the two senses of professionalism (independent and sponsored) as being opposed to one another. However, the analysis carried out so far is beginning to suggest that these two senses of professionalism are intertwined in complex ways. From an independent sense of professionalism, rural teachers seem to be challenging the policy notions of what counts as a good teacher. However, in light of the previous excerpts, it could be argued that teachers are also negotiating their professionalism in multiple, not always dichotomous, ways. This point will be explored further in the discussion section of this paper. For now, let us continue exploring rural teachers' independent professionalism.

The identifications discussed so far in the construction of teachers' selves as successful professionals have included the school community. Beyond the local school context, their independent sense of professionalism also involves recognition from a third group of significant others. In particular, teachers refer to instances where people who are considered to hold some level of expertise in ELT have exalted their work. Included in this group, as the data suggests, are competent English language users (native speakers of English and local highly qualified teachers), local writers of ELT materials, and ELT researchers. Some teachers (Camilo, Maria, and Dora), for example, reported on situations where they have coached their students to participate in public performances in English at cultural celebrations in their schools or in regional school contests. The fact that native speakers of English or other local specialists were assessing the teachers' work from a judging panel or even simply from the audience was an important factor in shaping their positive perceptions of the sort of professionals they are. This is especially the case when students have won competitions or been verbally complimented on their performance. Here is how Camilo put it:

\footnotetext{
With the pupils made a presentation in English about Billy Wilkings, a story of two cowboys, short, I adapted the text, I wrote the adaptation, I made up a few lines... The kids participated and we signed for the municipal championship of bilingualism. In the competition with about 5 or 6 other schools, and on that occasion I won. I beat the others with that presentation in English... In the judging panel there was a teacher from London, so I heard... Some teachers who were experts in English but from Armenia, and they were the jurors. I won, I won, we won with the kids that prize, and the additional prize was a place to participate in the championship of Bilingualism but at the department level. (Camilo, interview 1)
}

Camilo made several points here to build an argument of professional success. First, he emphasized all the things that he did: he made a presentation, he adapted the script, he made up a few lines in the script, and thus he won the prize. At the same time, while he clearly stated the things he did, he then included the students. He said, "We won with the kids" and the people who awarded the prize and assessed their work were ELT specialists of some sort. The recognition of the work done allowed both teacher and students to participate in another contest at a wider regional level with many other contenders from other municipalities. Although they did not win again, having reached that point meant his work was acknowledged by people who held some authority in his field. An experience such as that one, at the same time, contributed to constructing an image of himself as a good teacher grounded in the same alternative narrative of success as the cases shown above (i.e., their work being acknowledged by significant others). 
In connection with this previous point, most teachers also seem to interpret their being considered to participate in this study as another gesture of recognition from an expert. The fact that a researcher was interested in knowing about their work for some teachers represented a reason to be happy and feel important. For example, Hilda said that

This [the participation in this study] is a new experience, I had not had it and to be able to talk to a person that has more experience eh in English is -in the language, well, one is happy because one does not have a person who knows English well everyday here... the presence of another person gives you strength, to say well, wow I feel important because I was chosen as a teacher of English (laughs) as a teacher of English, that is. (Hilda, interview 2)

Hilda expressed her feelings of happiness and satisfaction for having been taken into account in this project as that positioned her as a professional with valuable experiences to share. In other words, her professional history mattered to a significant other, and that interest from me (the researcher), as Camilo stated, "motivates and makes oneself feel important” (Camilo, interview 2), especially because, as Dora explained, researchers are usually interested in urban locales and the rural contexts tend to be ignored.

\section{Self-identifications}

In addition to recognizing others as sources of identification as successful professionals, the participating teachers also used self-identifications to reinforce the same image. For example, they brought up the achievements with their students as well as their own achievements as arguments to shape their positive image. That was certainly the case with Maria and Clara, who found in their students' scores on the national examinations evidence of their accomplishments as professionals. On this particular issue, Clara said:

Every year we improved a little, [the scores] were increasing a little since I arrived as fortunately the area of English has been improving. Sometimes a lot, on other occasions very little, but fortunately since I am here it has never lowered... It is precisely because of that, fear it may lower, that the percentage of the school decreases, because of that I have seen the need to focus on reading comprehension in English. (Clara, interview 1)

Clara referred to how her students had been progressively improving the results they obtained on the national examinations since she arrived at the school nine years ago. She clearly stated that the improvement was slight but steady, and although it is perhaps still very far from the policy goals, those scores serve the purpose of establishing her identity as an effective professional. Interestingly, as the study in its entirety shows, her achievement seems to be grounded in the decisions she made in negotiating the policy. For example, Clara decided to focus on grammar and reading comprehension in her lessons as an attempt to align her practices to the focus of Pruebas Saber 11. This illustrates what Ball (2003) argued when he said that education policy is likely to shape teachers' sense of who they are and what they should do because, usually over the long term, teachers come to assimilate it as the right thing to do. That is, teachers' alternative notions of professional success do not necessarily imply moving completely away from policy requirements. External pressures such as national examinations and school rankings do have an effect on teachers' practices and thus on their sense of professional being (see Cruz-Arcila, 2018a).

Not all positive self-identifications, however, were constructed in relation to Pruebas Saber 11. Dora's notion of success was built from the idea that, thanks to her work, her primary pupils now seem to be eager to use English at school. This is remarkable because, as she explained, when she arrived at that school, her students were very shy and would not even interact with her in Spanish. She said that, now, not only are they willing to greet and sing to her and other teachers at the school in English but they are also keen on taking part in a special annual event she organizes at the school that she calls The Bilingualism Project, a day where students perform 
different sorts of activities in English (e.g., plays, songs, poems, rhymes) for the rest of the school.

\section{Discussion}

The discrepancy between teachers' emic identification and the ways in which they are being represented in education policy raises major implications regarding a need to reconcile different strands of beliefs around who teachers are and what they should know and do, in other words, their professionalism. These strands, as the data have shown and as Figure 5 below illustrates, can be understood as two directions and perspectives from which identifications of teachers may be established. In Colombia, it appears that an etic perspective of identification underlies an often more common or default way to define who a good (and thus successful) teacher of English can be. This is the perspective of policy makers and regulatory bodies (e.g., MEN, regional offices of education). They have tended to develop language policy aligned with market needs under the consultancy of transnational ELT agencies, which sometimes act as another regulatory body. Coming back to Leung (2009), this is the perspective underpinning the idea of sponsored professionalism. By looking at the structure of language policy in Colombia, it becomes apparent that at least three main characteristics constitute this view: A good teacher (a) holds at least high intermediate level of English, (b) is familiar with and uses current mainstream communicative methodologies, and (c) can follow instructions from policy makers effectively. The first characteristic is evident in the urgency and pressure put on teachers to take proficiency tests and language courses in pursuing the minimum desirable B2 level of proficiency stated in the policy. The second is apparent, for example, in the curricular descriptors developed following the CEFR, which explicitly endorse communicative principles of language learning and teaching. The third can be seen in the expectation of teachers to mainly act as technicians who need to apply methodologies to achieve pre-established goals, as pointed out above.
These characteristics echo what, in the theory of policy enactment (Ball, Maguire, \& Braun, 2012; Ball, Maguire, Braun, Perryman, \& Hoskins, 2012) is known as deliverology, "a technology of performance [that] [...] establishes connections between the aspirations of authorities and the activities of individuals and groups" (Ball, Maguire \& Braun, p. 139). The notion of deliverology seems to be a good proxy for the dynamics of etic identifications of teachers, whose professionalism is mainly determined by how well they fulfil the three aforementioned characteristics, which are thought to be necessary in order to get policy done.

In contrast, from an emic identification perspective, this study shows that there is an alternative and more socially grounded view of what professional success might mean. As reported above, recognition of teachers' work on the part of their significant others stands out as the most important element underlying this alternative view. As shown, sometimes this recognition takes the form of verbal or symbolic acknowledgement from members of the school community. Other times, teachers' reflections on student achievements become another type of self-recognition that strengthens their positive image as professionals. ELT specialists constitute one special source of recognition too. Although this group of significant others is not in constant contact with teachers and may in fact be more likely to hold external views on their work, they can contribute to the construction of teachers' alternative narratives of success. As noted, this may happen when specialists undertake actions that exalt and boost teachers' practices as opposed

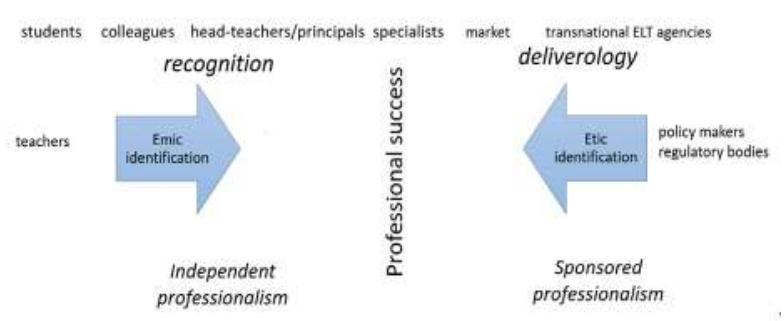

Figure 5 Strands of belief about professional success 
to actions aimed mainly at instructing teachers on what they should do.

As noted above, this approach to teachers' work is consistent with Leung's (2009) notion of independent professionalism. This sense of professionalism highlights the possibility teachers have to interrogate the relevance and feasibility of, for example, ambitious policy goals, fixed learning descriptors, and mainstream methodologies in light of given circumstances and act accordingly. Although rural teachers' interrogation of these factors appears to be rather intuitive, they have been able to creatively negotiate them in a variety of forms, relying mainly on their experiential judgement. As demonstrated, this negotiation has involved a reinterpretation of policy goals, a resistance to learning descriptors, and the use of teaching methodologies that are widely regarded as traditional and having little value in the current communicatively dominated discourses of ELT pedagogy (Cruz-Arcila, 2018a).

\section{0}

As observed, though, in this emic identification of teachers, there is still room for policy compliance. Teachers cannot completely escape from policy demands. This is why recognition from head teachers and school principals and even from teachers themselves is likely to be given in relation to doing better than before on national examinations and thus being a bit closer to the idealizations of policy. In fact, teachers like Hilda, Clara, and Maria highlighted their test scores in conflicting and complex ways, which shows that they are not only challenging their positioning as ineffective teachers, but also creatively negotiating their professionalism. In this negotiation, symbolic social recognition, while important, is not always enough to configure an alternative image of professional success. Therefore, teachers' sense of independent professionalism can be understood not simply as the opposite of the sponsored professionalism but, rather, as a creative identity the teachers have constructed for themselves in the gray area between the policy world and the local contexts where they teach.
Hall (1996) explained that identities are constructed through difference, they can work as a meeting point, a suture between larger ideological discourses and practices on the one hand and individual subjectivities on the other. From this view, it can be argued that teachers' sense of independent professionalism serves as that suture between what they feel they are doing right and what policy requires them to do. In this scenario, Figure 6 illustrates how the group of rural teachers who participated in this study seem to construct their professionalism. Their independent sense of successful professionals works as a creative identification that permits them to negotiate between policy forces and local sociocultural complexities, where symbolic recognition as well as attempting to deliver on policy could both play an important role.

This research thus suggests that there is a need to consider these first-hand understandings of professionalism in the ways teachers in general, and rural teachers of English in particular are represented. This does not necessarily imply a radical rejection of sponsored views of professionalism but a reconfiguration of the belief systems of what teachers should know and do. Surely, addressing market needs in language policy and considering the developments of the scientific tradition of ELT can be proven to be of higher value if, instead of

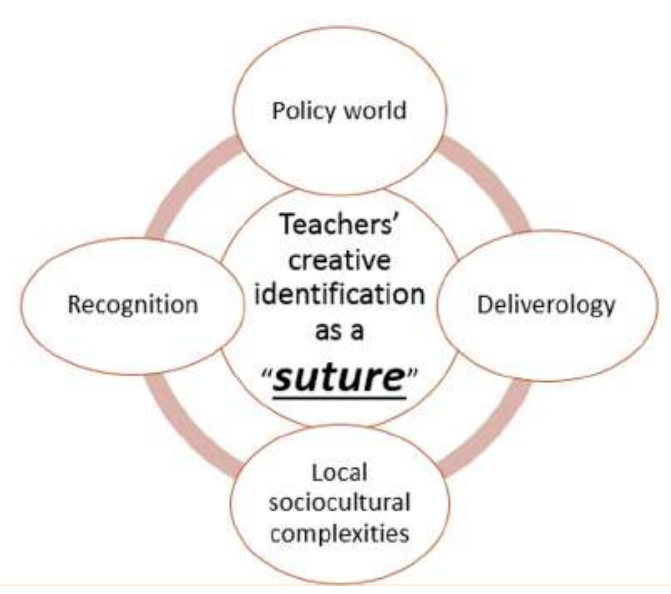

Figure 6 Independent professionalism as a suture 
being imposed, they are integrated and brought into negotiation with social needs and teachers' situated expertise. Therefore, instead of a situation where teachers are maligned for being unable to attain goals, they can be empowered to build from what they already know and do and perhaps carry out actions aimed at working toward the targets of policy makers. These targets, at the same time, need to be more in line with what students and families need, not only with what the market and transnational companies demand.

\section{Conclusions}

This paper has presented a detailed examination of how rural teachers in Colombia develop alternative narratives of professional success. The examination has shown that the many evident challenges teachers have to confront in rural schools, as well as not attaining policy goals, do not prevent them from construing an emic identification as successful professionals. The image of success and professionalism is not necessarily grounded in policy compliance. Instead, it is rooted in instances of value and appreciation of the teachers' work on the part of their significant others and on the part of the teachers themselves. This positive emic identification constitutes an interesting counterargument to what success can mean in the eyes of policy makers and stakeholders, where teachers are often expected to have the necessary skills to follow instructions as this is thought to be the only way to attain desired goals, and failing to attain goals is likely to be considered sufficient evidence to construct negative etic identifications of teachers as deficient and thus ineffective.

As demonstrated in this paper, the goal of professional ELT teachers in Colombian rural areas does not seem to be limited to what Schön (1983) called a technical rationality, implementing a given set of methods, strategies, and curricular guidelines. They appear to have developed a socially sensitive understanding of themselves and their profession that accounts for their own and their students' needs, problems, and aspirations. Language policy still comes to bear in this understanding as one imperative external pressure teachers inevitably have to deal with. Given these circumstances, I argued that there is a need for policymakers to also be aware of and consider the real (as opposed to ideal) contexts where policy is implemented and thus also consider ways in which teachers' work can be appreciated and potentiated.

\section{References}

Ball, S. J. (2003). The teacher's soul and the terrors of performativity. Journal of Education Policy, 18(2), 215-228. https://doi.org/10.1080/0268093022000043065

Ball, S. J., Maguire, M., \& Braun, A. (2012). How schools do policy: Policy enactments in secondary schools. Routledge. https://doi.org/10.4324/9780203153185

Ball, S. J., Maguire, M., Braun, A., Perryman, J., \& Hoskins, K. (2012). Assessment technologies in schools:'Deliverology'and the 'play of dominations. Research Papers in Education, 27(5), 513-533. https://doi.org/10.1080/02671522.2010.550012

Barkhuizen, G. (2016). Narrative approaches to exploring language, identity and power in language teacher education. RELC Journal, 47(1), 25-42. https://doi. org/10.1177/0033688216631222

Barkhuizen, G. (2017). Language teacher identity research: An introduction. Reflections on language teacher identity research (pp. 1-11). Routledge. https://doi. org/10.4324/9781315643465

Borg, S. (2009). Language teacher cognition. In A. Burns \& J. Richards (Eds.), The Cambridge guide to second language teacher education (pp. 163-171). Cambridge University Press.

Brubaker, R., \& Cooper, F. (2000). Beyond "identity". Theory and Society, 29(1), 1-47. https://doi. org/10.1023/A:1007068714468

Colombia, Ministerio de Educación Nacional. (2005). Bases para una nación bilingüe y competitiva. [The bases for a competitive bilingual nation] [html] http://www. mineducacion.gov.co/1621/article-97498.html

Colombia, Ministerio de Educación Nacional. (2014). Programa nacional de inglés 2015-2025: documento de socialización. [National Program of English 20152025: Working document] Bogotá. http://www. colombiaaprende.edu.co/html/micrositios/1752/ articles-343287_recurso_1.pdf. 
Colombia. Ministerio de Educación Nacional. (2018). Colombia Bilingüe. [Bilingual Colombia]. http://aprende. colombiaaprende.edu.co/es/colombiabilingue/86689

Correa, D., Usma, J., \& Montoya, J. C. (2014). El programa nacional de bilingüismo: un estudio exploratorio en el departamento de Antioquia, Colombia [National bilingualism program: An exploratory study in the department of Antioquia, Colombia]. Íkala, Revista de Lenguaje y Cultura, 19(1), 101-116.

Cruz-Arcila, F. (2017). Interrogating the social impact of English language teaching policies in Colombia from the vantage point of rural areas. Australian and International Journal of Rural Education, 27(2), 46-60.

Cruz-Arcila, F. (2018a). ELT policy interpretations and translations in rural Colombia. Current Issues in Language Planning, 19(4), 363-382, https://doi.org/10.1080/ 14664208.2017 .1377903

Cruz-Arcila, F. (2018b). The wisdom of teachers' personal theories: Creative ELT practices from Colombian rural schools. PROFILE, Issues in Teachers Professional Development, 20(2), 65-78. https://doi. org/10.15446/profile.v20n2.67142

Day, C., Kington, A., Stobart, G., \& Sammons, P. (2006). The personal and professional selves of teachers: stable and unstable identities. British Educational Research Journal, 32(4), 601-616. https://doi. org/10.1080/01411920600775316

Delgado, M. (2014). La educación básica y media en Colombia: retos en equidad y calidad [Elementary and middle education in Colombia: equity and quality challenges]. Fedesarrollo (Ed.). http://www. fedesarrollo.org.co/wp-content/uploads/2011/08/ La-educaci\%C3\%B3n-b\%C3\%A1 sica-y-media-enColombia-retos-en-equidad-y-calidad-KAS.pdf

El Espectador. (2016, November 15). Colombia sigue rajado en inglés [Colombiastill flunks English].ElEspectador. https://www.elespectador.com/noticias/educacion/ colombia-sigue-rajado-ingles-articulo-665607

Flores, M. A., \& Day, C. (2006). Contexts which shape and reshape new teachers' identities: A multi-perspective study. Teaching and Teacher EAducation, 22(2), 219 232. https://doi.org/10.1016/j.tate.2005.09.002

Fortich Mesa, R. (2013, September 6). Rajados en inglés [Flunking English]. El Universal. https://www.eluniversal.com.co/opinion/columna/ rajados-en-ingles-5193-FQEU221985

Gee, J. P. (2000). Identity as an analytic lens for research in education. Review of Research in Education, 25(1), 99 125. https://doi.org/10.3102/0091732X025001099
Gossaín, J. (2014, February 27). ¿Por qué es tan mala la educación en Colombia? [Why education is so poor in Colombia?] El Tiempo. http://www.eltiempo. com/archivo/documento/CMS-13570938

Graves, K. (2009). The curriculum of second language teacher education. The Cambridge guide to second language teacher education (pp. 115-124). Cambridge University Press.

Guerrero, C.H. (2010). The portrayal of EFL teachers in official discourse: The perpetuation of disdain. PROFILE, Issues in Teachers' Professional Development, 12(2), 33-49.

Hall, S., (1996). Who needs identity? In S. Hall, \& P. du Gay (Eds.), Questions of cultural identity. SAGE Publications. Sage.

Kanno, Y., \& Stuart, C. (2011). Learning to become a second language teacher: identities-in-practice. The Modern Language Journal, 95(2), 236-252. https:// doi.org/10.1111/j.1540-4781.2011.01178.x

Kayi-Aydar, H. (2015). Teacher agency, positioning, and English language learners: Voices of pre-service classroom teachers. Teaching and Teacher Education, 45, 94-103. https://doi.org/10.1016/j.tate.2014.09.009

Kubanyiova, M., \& Feryok, A. (2015). Language teacher cognition in applied linguistics research: Revisiting the territory, redrawing the boundaries, reclaiming the relevance. The Modern Language Journal, 99(3), 435-449. https://doi.org/10.1111/modl.12239

Lackin, M., \& Gasperini, L. (2004). La educación básica en áreas rurales: situación, problemática y perspectivas. [Elementary education in rural areas: Current situation, problems and perspectives] Educación para el desarrollo rural: hacia nuevas respuestas de politica. (pp. 81-188). UNESCO \& FAO.

Leung, C. (2009). Second language teacher professionalism. The Cambridge guide to second language teacher education (pp. 49-58). Cambridge University Press.

Lincoln, Y. S., Lynham, S. A., \& Guba, E. G. (2011). Paradigmatic controversies, contradictions, and emerging confluences, revisited. The Sage handbook of qualitative research, 4, 97-128.

López, H., \& Núñez, J. (2007). Pobreza y desigualdad en Colombia: Diagnóstico y estrategias. [Poverty and inequality in Colombia: Diagnosis and strategies] Bogotá: Departamento Nacional de Planeación.

Miller, J. (2009). Teacher identity. In A. R. Burns, Jack (Ed.), The Cambridge guide to second language teacher education (pp. 172-181). Cambridge University Press. 
Morgan, B. (2004). Teacher identity as pedagogy: Towards a field-internal conceptualisation in bilingual and secondlanguageeducation.InternationalJournalofBilingualEducation and Bilingualism, 7(2-3), 172-188. https://doi.org/10.1080/13670050408667807

Norton, B. (2000). Identity and language learning: Gender, ethnicity and educational change. Longman. https:// doi.org/10.21832/9781783090563

Norton, B. (2013). Identity and language learning: Extending the conversation. Multilingual Matters.

Olsen, B. (2016). Teaching for success: Developing your teacher identity in today's classroom ( $2^{\text {nd }} \mathrm{Ed}$.). Routledge. https://doi.org/10.4324/9781315631714

Pavlenko, A. (2003). "I never knew I was a bilingual”: Reimagining teacher identities in TESOL. Journal of Language, Identity, and Education, 2(4), 251-268. https://doi.org/10.1207/S15327701JLIE0204_2

Perry, S. (2010). La pobreza rural en Colombia. [Rural poverty in Colombia] [PDF document] http://www. rimisp.org/wp-content/files_mf/1366386291Docu mentoDiagnosticoColombia.pdf

Programa de las Naciones Unidas para el Desarrollo. (2011). Colombia rural: razones para la esperanza [Rural Colombia: Reasons for hope]. Programa de las Naciones Unidas para el Desarrollo.

Portafolio. (2017, November 16). Los retos que tiene Colombia para mejorar en el dominio de inglés [Colombia's challenges to improve English proficiency]. Portafolio. https://www.portafolio.co/economia/ gobierno/los-retos-que-tiene-colombia-para-mejorar-en-el-dominio-de-ingles-511663

Portafolio (2018, November 08). Colombia se raja en inglés [Colombia flunking English]. Portafolio. https://www. portafolio.co/tendencias/colombia-raja-ingles-78192

Richards, J. C. (2010). Competence and performance in language teaching. RELC Journal, 41(2), 101-122. https://doi.org/10.1177/0033688210372953

Sayer, P. (2012). Ambiguities and tensions in English language teaching: Portraits of EFL teachers as legitimate speakers. Routledge. https://doi.org/10.4324/9780203803714

Scott, D., \& Usher, R. (2011). Researching education: Data, methods and theory in educational enquiry ( $2^{\text {nd }} \mathrm{Ed}$.). Continuum International.
Scholes Gillings de González, B. (2011). The nature of recognition in TEFL teachers' lives. PROFILE, Issues in TeachersProfessional Development, 13(1), 75-87.

Schön, D. (1983). The reflective practitioner: How professionals think in action. Ashgate.

Sierra Piedrahita, A.M. (2016). Contributions of a social justice language teacher education perspective to professional development programs in Colombia. PROFILE Issues in TeachersProfessional Development, 18(1), 203-217. https://doi.org/10.15446/profile.v18n1.47807

Song, J. (2016). Emotions and Language teacher identity: Conflicts, vulnerability, and transformation. TESOL Quarterly, 50(3), 631-654. https://doi.org/10.1002/ tesq.312

Taylor, C. (1994). The politics of recognition. Multiculturalism: Examining the politics of recognition. (A. Gutmann, edition and introduction). Princeton University Press.

Troman, G. (1996). Models of the 'good'teacher: defining and redefining teacher quality. Contemporary issues in teaching and learning (pp. 20-37). Routledge.

Tsui, A. (2007). Complexities of identity formation: A narrative inquiry of an EFL teacher. TESOL Quarterly, 41(4), 657-680. https:// doi.org/10.1002/j.1545-7249.2007.tb00098.x

Varghese, M. M., Morgan, B., Johnston, B., \& Johnson, K. A. (2005). Theorizing language teacher identity: Three perspectives and beyond. Journal of Language, Identity, and Education, 4(1), 21-44. https://doi. org/10.1207/s15327701jlie0401_2

Varghese, M. M., Motha, S., Trent, J., Park, G., \& Reeves, J. (2016). Language teacher identity in (multi)lingual educational contexts. TESOL Quarterly, 60(3).

Wenger, E. (1998). Communities of practice: Learning, meaning, and identity. Cambridge University Press. https://doi.org/10.1017/CBO9780511803932

Wolff, D., \& De Costa, P. (2017). Expanding the language teacher identity landscape: An investigation of the emotions and strategies of a NNEST. The Modern Language Journal, 101(S1), 76-90. https://doi. org $/ 10.1111 / \operatorname{modl} .12370$

How to reference this article: Cruz-Arcila, Ferney (2020). Rural English Language Teachers' Identities: Alternative Narratives of Professional Success. Íkala, Revista de Lenguaje y Cultura, 25(2), 435-453. http://doi.org/10.17533/udea.ikala.v25n02a05 